\title{
Wheat yield scenarios for rainwater harvesting at Northern Sinjar Mountain, Iraq
}

\author{
Saleh Zakaria*, Nadhir Al-Ansari, Sven Knutsson \\ Department of Civil, Environmental and Natural Resources Engineering, Lulea University of Technology, Lulea, Sweden; \\ ${ }^{*}$ Corresponding Author: saleh.zakaria@1tu.se
}

Received 5 August 2013; revised 5 September 2013; accepted 14 September 2013

Copyright (C) 2013 Saleh Zakaria et al. This is an open access article distributed under the Creative Commons Attribution License, which permits unrestricted use, distribution, and reproduction in any medium, provided the original work is properly cited.

\begin{abstract}
Iraq is part of West Asia and North Africa (WANA) region. The area is known as dry land, famous with gap of crop yield as a result of the water shortage problem. Six basins with total catchment area of $614.19 \mathrm{~km}^{2}$ at rain-fed of Northern Sinjar District (Iraq) had been chosen to investigate both of the potential of rainwater harvesting (RWH) and three supplemental irrigation (SI) scenarios S1, S2, and S3 (100\%, $75 \%$, and $50 \%$ of full irrigation requirement) to support the wheat yield (bread and durum) under various rainfall conditions for the study period 1990-2009. The results indicated that, the total volume of harvested runoff can be considered for irrigation practices, that reached up to $42.4,25.1,0.6,10.9$ $\left(\times 10^{6} \mathrm{~m}^{3}\right)$ during 1995-1996, 1996-1997, 1998-1999, and 2001-2002, respectively. The total irrigated area ranged between 10.9 - 5163.7 and 8.8 3595.7 (ha) for bread and durum wheat crop for the four selected seasons respectively. The yield scenarios for supplemental irrigation condition Y1, Y2, and Y3 give 68 - 9712, 94 - 12,999, and 105 - 22,806 Ton for bread wheat, and for durum wheat give 56 - 8035, 87 - 10,906, and 103 - 17,396 Ton.
\end{abstract}

Keywords: Rainwater Harvesting; Supplemental Irrigation; Wheat Yield; Sinjar; Iraq

\section{INTRODUCTION}

Dry land covers $95 \%$ of the total area of West Asia and North Africa (WANA region), where Iraq is located. Climate of the area is of Mediterranean-type. It is characterized by cold and rainy winters and temperate dry summers, with low rainfall amounts and limited renewable water resources in additional to summer drought period [1]. Two-thirds of global food production is provided by rain-fed land that represents about $80 \%$ of the world's agricultural land, certainly with higher risks in rain-fed agriculture due to water limitation [2].

In rain-fed land, rainfall is the principal source of water for rain-fed crops. In semi arid region rainfall is not enough for economic crop growth therefore supplementary irrigation is used when rainfall fails to satisfy suitable soil moisture conditions for the crop [3], in case there isn't available water for irrigation processes.

The amount of irrigation water through these processes cannot alone support economic crop production. Furthermore, the scheduling as well as water quantity for supplemental irrigation (SI) cannot be determined in advance due to uncertainty of rainfall [4].

At WANA region, the rainfall is widely fluctuating [5]. Therefore, rain-fed land in this region requires effective technique in terms of saving significant runoff water for irrigation purposes and this might be achieved by rainwater harvesting $(\mathrm{RWH})$ technique.

Some researchers $[6,7]$ have mentioned that there is no specific definition that is generally accepted to illustrate RWH, and others gave wide range for RWH definition with specific details, where they defined RWH as "a method for inducing, collecting, storing, and conserving local surface runoff for agriculture in arid and semi-arid regions" [8,9]. It is believed that the work cited by Boers [9] comprehensively defines RWH. RWH can also be defined as "the collection of runoff and its use for the irrigation of crops, pastures and trees, and for livestock consumption" [10]. The simplest definition that covers RWH content might be "the collection of runoff for its productive use" as given by Siegert, [11], who well documented some basic principles for planning, design and monitoring water harvesting for improved agricultural production.

Prinz [6] summarized six different forms of RWH according to the location, function and size of catchment 
area as follow: (1) Roof Top RWH, (2) RWH for Animal Consumption, (3) Inter-Row RWH, (4) Micro-catchment RWH, (5) Medium-sized Catchment RWH and (6) Large Catchment RWH (Macro-catchment).

As the result of the inability to take advantage of the groundwater and rivers in dry areas, the common purpose of above types of RWH is to generate a new water source for the region to ensure continuous access to the water for human, different kind of crops, and animals.

Thus, the productivity of the rainwater can be significantly improved by applying a specific technique such as Macro RWH, based on availability of a surface reservoir. By this technique the excess rainwater (runoff) is stored in small reservoirs of small earth dams with different sizes to be supplied later when required to satisfy the crops requirements. This will increase the productivity of the agricultural land especially when it is combined with specific irrigation system, such as supplemental (SI) and deficit irrigation (DI) [12-14].

RWH had been practiced in dry land that has annual rainfall of $100-300 \mathrm{~mm}$, where it is not enough for crops growth to balance potential evapotranspiration (ET) of crops [1].

There are three important technologies to improve water productivity and the management of scarce water resources: first, supplemental irrigation (SI), second, water harvesting $(\mathrm{WH})$, third, improving crop water productivity, such as improved germplasm, fertility and cultural practices [5].

There are several factors affecting the crop yield, and the water quantity and nutrients are the most important [4].

One of the primary ways to enhance rain-fed agricultural production is to make more effective use of the rainfall, i.e. using water harvesting. It increases the volume of water per unit cropped area, reduces dry effect and increases the productivity of rainwater [15].

There is inconsistency in agricultural production in arid and semi-arid region that has a fluctuated agricultural process as the result of fluctuation in rainfall.

As a result, developing countries are, internally, food insecure due to a complex interaction between climatic and human factors. Although dry lands are experiencing significant challenges, their productivity can be increased, and it can produce enough food to sustain livelihoods [16].

For the period of 2015-2030, it was estimated that 80 percent of the required increase in food production (yield increases) had to come from higher cropping intensities [17].

In order to guarantee food and water security in dry land, some factors should be taken into consideration, especially, deficits factors for each of water, knowledge and investment for development of agricultural research, in addition to yield gap [18].

Some countries of WANA region like Turkey, Iran, Iraq, Syria and Saudi Arabia, produce about 95 percent of the wheat in West Asia, the production largely fluctuates where wheat yield ranges between 0.7 tones/ha (Iraq) to 4.5 tones/ha (Saudi Arabia), due to highly erratic rainfall causes substantial fluctuations in crop yield [19].

In Iraq, the production of wheat does not constitute more than one-third of the required supply quantities of this crop annually [20]. Adary et al., 2002 [21], investigate wheat yield under supplemental irrigation (SI) in Iraq. They stated that, both yield and water productivity increased using SI in conjunction with rainfall, by using only $68 \mathrm{~mm}$ of irrigation water for rain fed wheat, and the yield increased in one season from $2.16 \mathrm{~T} /$ ha to 4.61 $\mathrm{T} /$ ha i.e. more than $100 \%$.

In Northern Iraq, 284 farms were used to study the impact of SI on the wheat yield. The results showed that SI increased wheat yield by $100 \%$ [22].

In Iraq, the production and consumption of wheat crop are not equally distributed across the country. The major wheat quantities, that are available for consumption, come from outside Iraq.

Iraqi Central Statistics office of Ministry Planning [20] studied the wheat yield in Iraq for the period 2002-2010 and concluded that, in some years there is a substantial decrease in the yield in rain-fed land, mainly, because of the limited rainfall through these years. This requires a commensurate agricultural policy and affecting production data, works toward the expansion of artificial wells in addition to the development and establishment of new irrigation projects, and uses of some techniques that will contribute to the formation of new water sources such as RWH.

The main objective of this research is to test rainwater harvesting technique for wheat crop yield production in dry rain-fed farms at Sinjar district, north west of Iraq, using wheat crop yield-water relationship that conducted by International Center for Agricultural Research in the Dry Areas (ICARDA) [23]. Three scenarios of supplemental irrigation $(100 \%, 75 \%$ and $50 \%)$ of full irrigation requirements with, various rainfall conditions were used. Furthermore two types of wheat (bread and durum) were considered.

\section{STUDY AREA}

Northern Sinjar District (Figure 1) is located within Nineveh province in northwest Iraq, near the international Iraq-Syria borders. Sinjar district is characterized by its semi-arid climate, where rainfall totals are low with an uneven distribution. Rain water is the main source for agricultural practices in Sinjar area. The average annual rainfall is about $286.7 \mathrm{~mm}$ for the study period 19902009 which is not sufficient to maintain crops growth. 
Table 1 shows seasonal fluctuation rainfall depths on study area for the period (1990-2009). In addition, the rainfall distribution also varies widely.

Sinjar and the surrounding land are famous for the cultivation of wheat and barley. Bread wheat (Triticumaestivum L.) is the main crop while durum wheat (Triticumturgidum L.) is of less attention.

The rainy season extends from November to May. during this season, the runoff water flows in the valleys from Sinjar Mountain toward north to the Iraqi and Syrian border. Maximum monthly evaporation is usually recorded in July $563.4 \mathrm{~mm}$ and it drops to $57.4 \mathrm{~mm}$ in December [24]. The soil in the study area has low organic content and consists of sandy loam, silty loam and silty clay loam [25].

\section{METHODOLOGY}

The methodology used for this research is well documented by $[13,14,26]$, which can be summarized as discussed below. A catchment area of six basins with a total area of $614.19 \mathrm{~km}^{2}$ has been selected to estimate the harvested runoff for four rainfall seasons at rain-fed farm of Northern Sinjar district in order to support and to estimate the amount of two types of wheat yield (bread and durum). The runoff estimation depends on the Land use map for the six selected basins (Figure 2).

The seasons 1995-1996, 1996-1997, and 1998-1999 were selected based on the level of total rainfall depths that reached maximum (478.1), average (307.6) and minimum (110.1) rainfall depths ( $\mathrm{mm}$ ) along the study period (1990-2009) respectively. In addition the season 2001-2002 of rainfall depth (257.5) mm was also selected in order to include another rainfall depth within the range $200-300$ ( $\mathrm{mm})$.

Table 2 shows the monthly rainfall depth along the wheat season growth on North Sinjar through the selected seasons.

Runoff volumes were estimated from individual daily rainfall storms, that fall on the six basins, using Watershed Modeling System (WMS) based upon the Soil Conservation Service runoff curve number method (SCS-CN) (now is Natural Resource Conservation Service or NRCS). These harvested runoff volumes where accumulated and stored in individual six reservoirs located at the outlet of the basins and their water is to be used later for supplemental irrigation (SI) to irrigate the wheat crop. The calculation of wheat yield was conducted in two phases in the first, the harvested water was used to irrigate the crop of bread wheat and the second was to use the same water to irrigate durum wheat crop. It should be noted that, in order to ensure suitable initial moisture contain of the soil farm, the start date of wheat growing season of 210 days of long begins when the rainfall on the Sinjar's farm reaches a proper depth $(10 \pm 2 \mathrm{~mm})$.

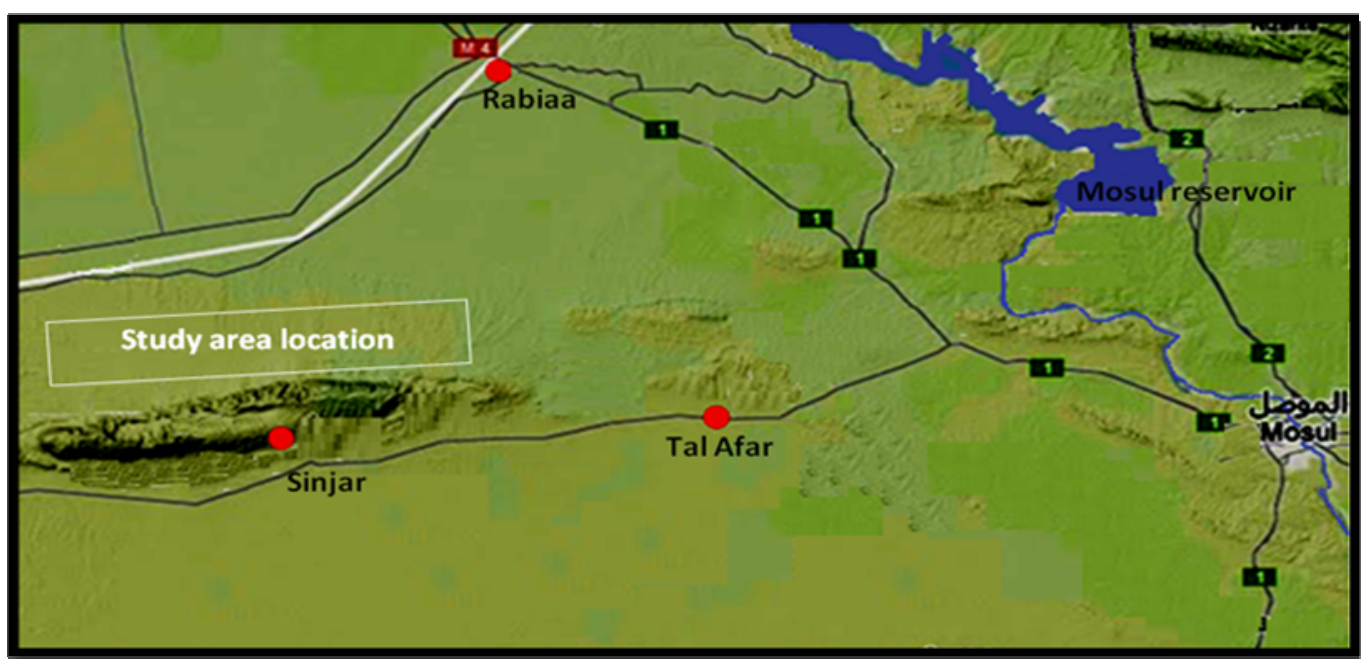

Figure 1. The study area of Northern Sinjar District (source google map).

Table 1. Seasonal rainfall depths on study area (North Sinjar) for the period 1990-2009.

\begin{tabular}{cccccccccc}
\hline Season & $\mathbf{9 0 - 9 1}$ & $\mathbf{9 1 - 9 2}$ & $\mathbf{9 2 - 9 3}$ & $\mathbf{9 3 - 9 4}$ & $\mathbf{9 4 - 9 5}$ & $\mathbf{9 5 - 9 6}$ & $\mathbf{9 6 - 9 7}$ & $\mathbf{9 7 - 9 8}$ & $\mathbf{9 8}-\mathbf{9 9}$ \\
\hline Rainfall (mm) & 260.4 & 360.8 & 261.3 & 390.9 & 377.3 & 478.1 & 306.2 & 256.8 & 110.1 \\
Season & $\mathbf{9 9 - 0 0}$ & $\mathbf{0 0 - 0 1}$ & $\mathbf{0 1 - 0 2}$ & $\mathbf{0 3 - 0 4}$ & $\mathbf{0 4 - 0 5}$ & $\mathbf{0 5 - 0 6}$ & $\mathbf{0 6 - 0 7}$ & $\mathbf{0 8 - 0 9}$ \\
Rainfall (mm) & 151.4 & 429.3 & 257.5 & 254.9 & 256.8 & 307.6 & 243.6 & 136.3 \\
\hline
\end{tabular}




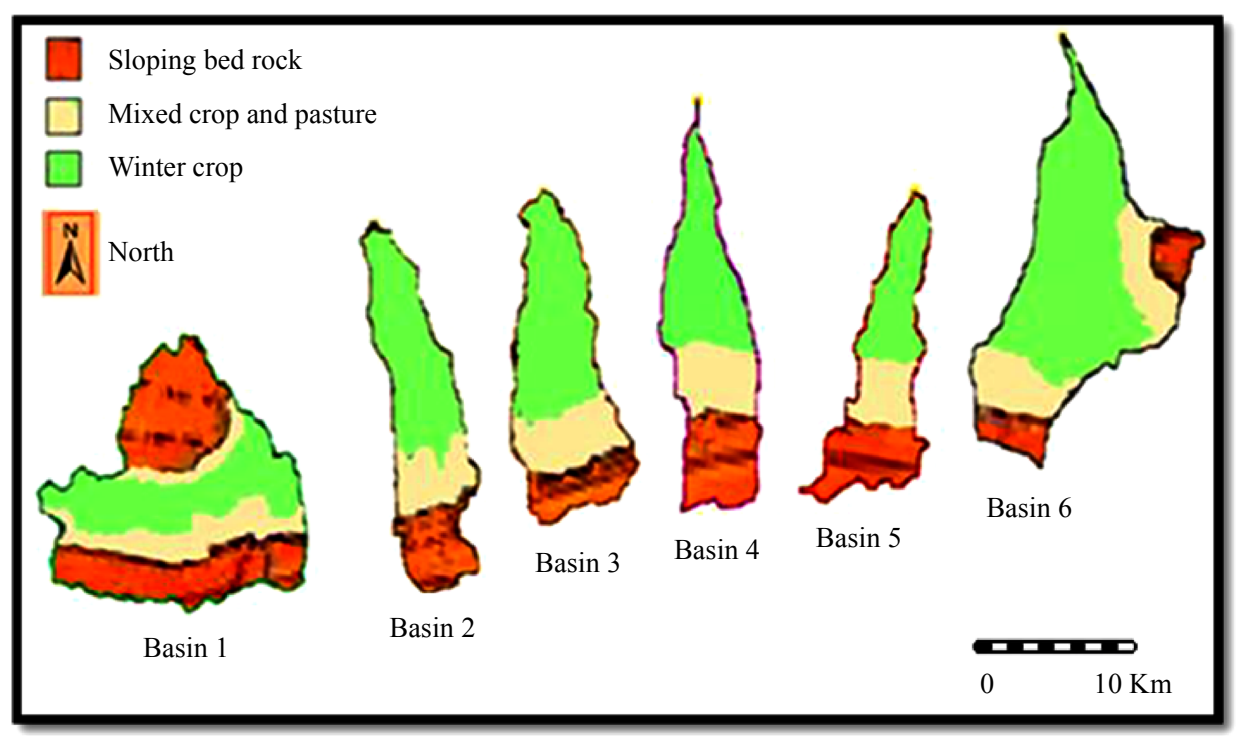

Figure 2. Land use map for the six basins for Northern Sinjar District (source [13]).

Table 2. Monthly rainfall ( $\mathrm{mm})$ on North Sinjar through the selected seasons.

\begin{tabular}{ccccccccc}
\hline Season & Dec. & Jan. & Feb. & Mar. & Apr. & May. & Total & Rainfall Notes \\
\hline $\mathbf{1 9 9 5 - 1 9 9 6}$ & 0.0 & 229.4 & 80.8 & 122.2 & 23.6 & 22.1 & 478.1 & Max. Season \\
$\mathbf{1 9 9 6 - 1 9 9 7}$ & 159.8 & 17 & 64.6 & 47.7 & 14.1 & 3.0 & 306.2 & Average season \\
$\mathbf{1 9 9 8 - 1 9 9 9}$ & 3.2 & 29.7 & 35.9 & 24.1 & 17.2 & 0.0 & 110.1 & Min. season \\
$\mathbf{2 0 0 1 - 2 0 0 2}$ & 51.0 & 34.6 & 10.3 & 109.6 & 49.2 & 2.8 & 478.1 & Additional season \\
\hline
\end{tabular}

The irrigation water requirements of SI can be estimated by Supplemental Irrigation model using computer model (based on MATLAB software). The estimation is based on rainfall depth, soil water storage and crop water requirements. Three irrigation scenarios S1 (100\%), S2 (75\%), and S3 (50\%) of full irrigation requirements were selected to be used in order to show the effect and the benefit of supplemental irrigation for reducing the amount of water required for irrigation.

A linear programming computer model technique (The Optimization Model) has been used to optimize crop area that could be irrigated by the above supplemental irrigation levels which give three scenarios of crop yield (Y1, $\mathrm{Y} 2$, and Y3) respectively under supplemental irrigation condition.

Wheat crop could be produced in the rain-fed farm depending on rain water alone without irrigation process which represent scenario Y4.

Wheat crop was selected as the main crop for Sinjar district. The wheat yield per unit area can be estimated using yield relation with total applied water, that conducted by researchers of International Center for Agricultural Research in the Dry Areas (ICARDA) [23].

The total grain of wheat yield can be estimated considering the irrigated area under three level of supple- mental irrigation $(100 \%, 75 \%$, and $50 \%)$ of full irrigation requirements.

\section{BACKGROUND OF YIELD RELATION WITH TOTAL APPLIED WATER}

Zhang and Oweis (1999) [23], analyzed the experiments results of supplemental irrigation (SI) that carried out in Syria to evaluate water-yield relations for bread wheat (Triticumaestivum L.) and durum wheat (Triticumturgidum L.), the time span where covered ten years of experiments. The sow date was before mid-December. They developed quadratic crop production functions with the total applied water (rainfall + irrigation water) in order to estimate the levels of irrigation water for maximizing yield, net profit and levels to which the crops could be under irrigated without reducing income below that which would be earned for full SI under limited water resources. For the above SI experiments, irrigation water was applied using different irrigation system (a line-source sprinkler system, basin irrigation, and a drip irrigation system). The maximum water applied was the summation of the rainfall and irrigation water. Different level of Irrigation water was used. The minimum water applied was the rain-fed treatments without irrigation, in this 
case it possible to evaluate the crop yield under rainfall condition alone without irrigation. It was concluded that the SI scenarios for maximizing the profit under limited water resource conditions or for a targeted yield of $4-5$ $\mathrm{t} /$ ha were recommended for sustainable utilization of water resources and higher water-use efficiency [23].

For the rain-fed farm there are two important conditions:

The first is under rain-fed conditions, the evapotranspiration (ET) ranged 200 to $460 \mathrm{~mm}$ for both bread and durum wheat, depending on the seasonal rainfall depth. The corresponding grain yield ranged from 0.35 to $4 \mathrm{t} / \mathrm{ha}$ for bread wheat and 0.6 to $5 \mathrm{t}$ /ha for durum wheat.

The second is under SI conditions, ET ranged from 300 to $600 \mathrm{~mm}$, depending on the combined amount of water (rainfall + irrigation) with corresponding grain yield ranged from 2.3 to $7.5 \mathrm{t} /$ ha for bread wheat, and ET ranged from 300 to $650 \mathrm{~mm}$, and grain yield ranged from 3.6 to $8.4 \mathrm{t} /$ ha for durum wheat.

Grain yield linearly increased with increasing rainfall and irrigation $(\mathrm{P}+\mathrm{W})$ up to $450 \mathrm{~mm}$ during the growing season. The increase in grain yield per unit of $\mathrm{P}+\mathrm{W}$ gradually decreased when $\mathrm{P}+\mathrm{W}$ was above $450 \mathrm{~mm}$. This response of yield to $\mathrm{P}+\mathrm{W}$ can be described using a quadratic equation as follows [23]:

$$
Y(W)=b_{0}+b_{1}(P+W)+b_{2}(P+W)^{2}
$$

where $\mathrm{Y}$ is grain yield $(\mathrm{t} / \mathrm{ha}), \mathrm{W}$ is the irrigation water $(\mathrm{mm}), \mathrm{P}$ is the precipitation $(\mathrm{mm})$ during the growing season. $\mathrm{b}_{0}=(-6.4335), \mathrm{b}_{1}=(0.0378)$ and $\mathrm{b}_{2}=$ $(0.00002778)$ represent the regression coefficients. A highly significant polynomial relationship existed between grain yield and the total applied water $\left(\mathrm{R}^{2} 0.84\right)$, with a minimum requirement of $203 \mathrm{~mm}$ water for initial grain yield. The highest grain yield required 680 and $750 \mathrm{~mm}$ with corresponding yields of 6.42 and $6.65 \mathrm{t} / \mathrm{ha}$ for the bread and durum wheat respectively.

\section{RESULTS AND DISCUSSION}

Sinjar rainfall is very similar to that recorded by ICARDA at Tel Hadya research farm at Syria, Quick comparison between rainfall of Tel Hadya and Sinjar shows that both rainfalls are low, fluctuate with time and are of an uneven distribution. Although the study period at Sinjar (17 seasons) is longer than that adopted by ICARDA (10 seasons for the period 1985-1996, with average rainfall depth of $332 \mathrm{~mm}$ ) but Sinjar rainfall decreased less than $200 \mathrm{~mm}$ three times during dry seasons (1998-1999, 1999-2000 and, 2008-2009). Table 3 shows the start and end date seasons of wheat crop for the selected seasons at North Sinjar area.

For the study area, all six basins have identical characteristics. In such a case, for the rainy season, the influential factors (type, size and slope of the catchment area, curve number value, antecedent moisture conditions, distribution and amount of the rainfall) act together to produce amount of runoff that directed by gravity and stored in an individual six reservoirs according to their capacity, then other factors like the reservoirs size and the evaporation losses from its surface area will affect the storage of harvested water. According to the above and by using WMS that is based on curve number method, it's possible to estimate the daily water volume of the harvested runoff that was accumulated in the reservoirs along the seasons (Figure 3). This harvested runoff water that was stored in an individual six reservoirs can be used later for supplemental irrigation processes.

The maximum annual harvested runoff volumes that reached the reservoir no. 1 to no. 6 are $17.25,7.68,6.11$, $2.84,3.46$ and $5.0\left(10^{6} \mathrm{~m}^{3}\right)$ respectively during the wet season (1995-1996). While the minimum annual harvested runoff volumes that reached the reservoir no. 1 to no. 6 are $0.34,0.12,0.03,0.04,0.03$ and $0.01\left(10^{6} \mathrm{~m}^{3}\right)$ respectively during the dry season (1998-1999).

The total volume of harvested runoff for all basins together reached up to $42.4,0.60,10.9,11.7\left(10^{6} \mathrm{~m}^{3}\right)$ during the four selected seasons (1995-1996, 1996-1997, 1998-1999, and 2001-2002) respectively. The above results of estimating the total runoff volume indicates that the runoff volume can be considered for irrigation practices and especially for supplemental irrigation.

Tables 4 and 5 show the results of applying Supplemental Irrigation model that give actual irrigation demand for bread and durum crops at North Sinjar with three supplemental Irrigation scenarios (S1, S2, and S3) through the selected seasons. Certainly, reduction of total seasonal rainfall depth will increase the required actual irrigation demand in order to compensate soil moisture lack due to limited rain water. Such cases can be diagnosed through the selected seasons, for example, under full irrigation condition (scenario $\mathrm{S} 1$ ) the actual irrigation demand reached up to $358.6,452.6,661.0$ and, $382.0 \mathrm{~mm}$ for the wet, average, dry, and additional seasons res-

Table 3. Start and end dates season of wheat crop at North Sinjar.

\begin{tabular}{ccccc}
\hline Season & $\mathbf{1 9 9 5 - 1 9 9 6}$ & $\mathbf{1 9 9 6 - 1 9 9 7}$ & $\mathbf{1 9 9 8 - 1 9 9 9}$ & $\mathbf{2 0 0 1 - 2 0 0 2}$ \\
\hline Season start date & $13 / 12 / 1995$ & $06 / 12 / 1996$ & $30 / 12 / 1998$ & $02 / 12 / 2001$ \\
Season end date & $09 / 07 / 1996$ & $03 / 07 / 1997$ & $27 / 07 / 1999$ & $29 / 06 / 2002$ \\
\hline
\end{tabular}




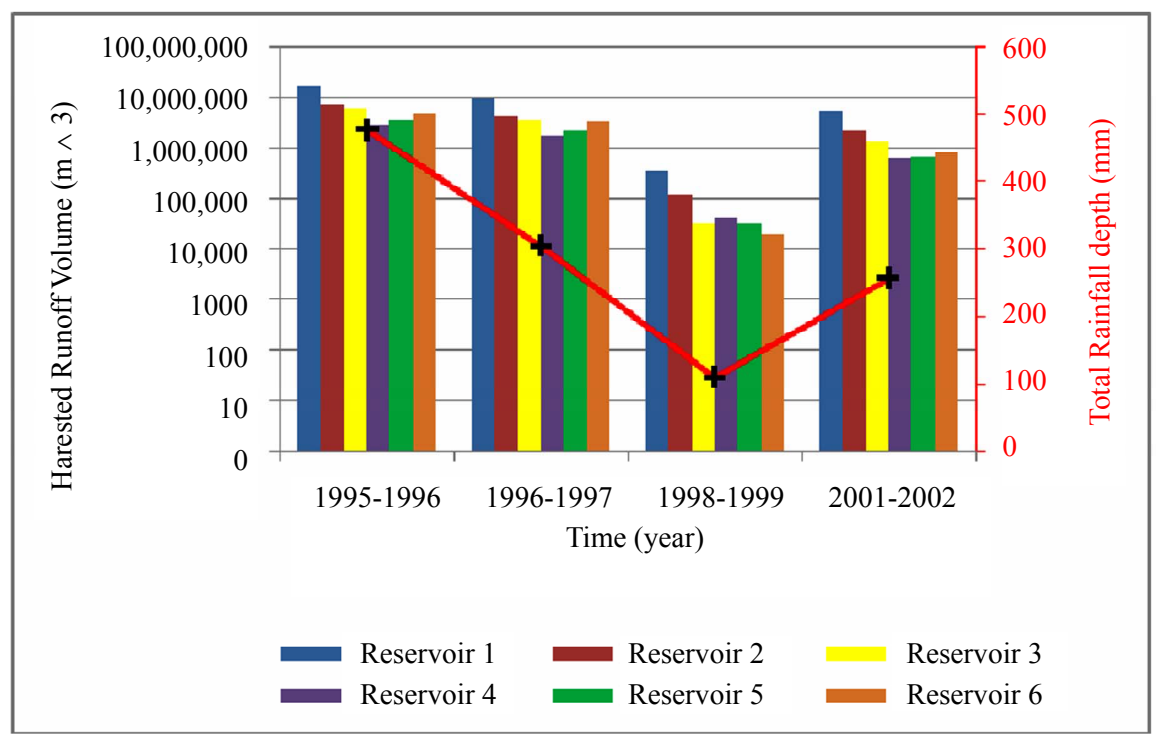

Figure 3. Harvested runoff at North Sinjar with total rainfall depth for the selected seasons.

Table 4. Monthly actual Irrigation demand $(\mathrm{mm})$ for bread wheat crop during the selected irrigation scenarios.

\begin{tabular}{|c|c|c|c|c|c|c|c|c|c|c|}
\hline \multirow[b]{2}{*}{ Year } & \multirow[b]{2}{*}{ Scenario } & \multicolumn{9}{|c|}{ Actual irrigation demand (mm) } \\
\hline & & Dec. & Jan. & Feb. & Mar. & Apr. & May & Jun. & Jul. & Total \\
\hline & S1 & 0.00 & 0.00 & 6.22 & 0.24 & 89.43 & 170.9 & 69.57 & 22.14 & 358.60 \\
\hline \multirow[t]{3}{*}{ 95-96 } & S2 & 0.00 & 0.00 & 0.00 & 0.00 & 31.01 & 122.7 & 52.18 & 16.61 & 222.51 \\
\hline & S3 & 0.00 & 0.00 & 0.00 & 0.00 & 0.00 & 69.98 & 34.79 & 11.07 & 115.83 \\
\hline & S1 & 8.89 & 14.37 & 35.96 & 33.76 & 116.1 & 163.8 & 72.39 & 7.38 & 452.66 \\
\hline \multirow[t]{3}{*}{ 96-97 } & $\mathrm{S} 2$ & 5.73 & 6.04 & 23.57 & 4.87 & 83.55 & 122.1 & 54.29 & 5.54 & 305.70 \\
\hline & S3 & 2.72 & 0.00 & 9.72 & 0.00 & 26.98 & 80.40 & 36.20 & 3.69 & 159.70 \\
\hline & S1 & 0.00 & 24.30 & 38.70 & 89.50 & 109.1 & 197.4 & 135.5 & 66.42 & 661.09 \\
\hline \multirow[t]{3}{*}{ 98-99 } & S2 & 0.00 & 16.41 & 23.08 & 63.40 & 75.25 & 148.1 & 101.6 & 49.82 & 477.73 \\
\hline & S3 & 0.00 & 8.52 & 7.46 & 37.46 & 41.21 & 98.73 & 67.79 & 33.21 & 294.37 \\
\hline & S1 & 7.04 & 11.03 & 43.49 & 55.96 & 46.18 & 146.9 & 71.34 & - & 382.01 \\
\hline 2001 & S2 & 3.82 & 3.23 & 25.43 & 41.17 & 8.26 & 102.2 & 53.51 & - & 237.66 \\
\hline 2002 & S3 & 0.76 & 0.00 & 6.01 & 26.38 & 0.00 & 35.28 & 35.67 & - & 104.11 \\
\hline
\end{tabular}

pectively. The aim should be to minimize the volume of these actual irrigation demands in order to achieve two important goals:

The first is to reduce the total cost and the second is to make the limited amount of available water could be adequate enough to irrigate largest agricultural area.

Using different levels of SI will satisfy most of the goals and help to minimize the total applied irrigation water to the farm by finding the minimum level of SI that maximize the irrigated area.

As an example, for the selected seasons, the total actual irrigation demand with scenario S2 reached 222.51,
305.70, 477.73, and $237.66(\mathrm{~mm})$ while, with scenario $\mathrm{S} 3$ it reached 115.83, 159.70, 294.37, and $104.11(\mathrm{~mm})$, for the wet, average, dry, and additional seasons respectively. These results show that supplemental irrigation of scenario S3 (50\% of full irrigation requirement) can save more water than scenarios S1 or S2, but this is require to be tested for crop yield production (as will be shown later) to be sure that scenario S3 give best result also according to crop yield. In general the characteristics of both crops (bread and durum) are similar, where both belong to the same crop quality (wheat) but durum wheat crop need more water during the growing season, where 
the increase of irrigation water for the durum ranged between 39 to $125(\mathrm{~mm})$ for the four selected seasons. Similar results were given by Zhang and Oweis [23].

Although the reduction of irrigation level will lead to reduce the yield per unit area, the real benefit will be due to the increase in agricultural irrigated area. This can be explained by the results of the Optimization Model (Tables 6 and 7) which show that the irrigated area for wheat (bread and durum) in hectare for individual reser- voirs for the three selected irrigation scenarios during the selected seasons and the total irrigated area for each scenario.

The results indicate that, (in case of bread wheat for example, Table 5), for the four selected seasons of 19951996 (wet), 1996-1997 (average), 1998-1999 (dry), and 2001-2002 (additional season) and for full irrigation requirement (scenario S1) the total irrigated area from all six reservoirs reached 1257.11, 1192.45, 10.89, and

Table 5. Monthly actual Irrigation demand $(\mathrm{mm})$ for durum wheat crop during the selected irrigation scenarios.

\begin{tabular}{|c|c|c|c|c|c|c|c|c|c|c|}
\hline \multirow[b]{2}{*}{ Year } & \multirow[b]{2}{*}{ Scenario } & \multicolumn{9}{|c|}{ Actual irrigation demand (mm) } \\
\hline & & Dec. & Jan. & Feb. & Mar. & Apr. & May & Jun. & Jul. & Total \\
\hline \multirow[t]{3}{*}{$95-96$} & $\mathrm{~S} 2$ & 0.00 & 0.00 & 0.00 & 0.00 & 68.56 & 142.0 & 63.20 & 23.01 & 296.8 \\
\hline & $\mathrm{S} 3$ & 0.00 & 0.00 & 0.00 & 0.00 & 10.01 & 87.34 & 42.13 & 15.34 & 154.8 \\
\hline & $\mathrm{S} 1$ & 8.89 & 15.22 & 42.41 & 66.49 & 139.4 & 186.3 & 90.52 & 10.61 & 559.8 \\
\hline \multirow[t]{3}{*}{ 96-97 } & $\mathrm{S} 2$ & 5.73 & 6.68 & 28.41 & 27.00 & 101.0 & 139.0 & 67.89 & 7.96 & 383.7 \\
\hline & $\mathrm{S} 3$ & 2.72 & 0.00 & 13.09 & 0.00 & 53.39 & 91.67 & 45.26 & 5.31 & 211.4 \\
\hline & $\mathrm{S} 1$ & 0.00 & 24.31 & 41.19 & 109.2 & 143.0 & 228.3 & 154.9 & 85.52 & 786.5 \\
\hline \multirow{2}{*}{ 98-99 } & $\mathrm{S} 3$ & 0.00 & 8.52 & 8.71 & 47.18 & 58.31 & 114.1 & 77.46 & 42.76 & 357.1 \\
\hline & $\mathrm{S} 1$ & 7.04 & 11.87 & 56.07 & 71.34 & 79.95 & 167.7 & 91.31 & - & 485.3 \\
\hline 2001 & $\mathrm{~S} 2$ & 3.82 & 3.86 & 34.86 & 52.71 & 29.30 & 122.1 & 68.48 & - & 315.1 \\
\hline 2002 & S3 & 0.76 & 0.00 & 12.27 & 34.07 & 0.00 & 57.37 & 45.66 & - & 150.1 \\
\hline
\end{tabular}

Table 6. Irrigated area (hectare) for bread wheat by six reservoirs for the three irrigation scenarios S1, S2 and S3 for the selected seasons.

\begin{tabular}{|c|c|c|c|c|c|c|c|c|}
\hline \multirow[b]{2}{*}{ Seasons } & \multirow[b]{2}{*}{ Scenario } & \multicolumn{7}{|c|}{ Irrigated area (hectare) } \\
\hline & & Res. 1 & Res. 2 & Res. 3 & Res. 4 & Res. 5 & Res. 6 & Total \\
\hline \multirow{3}{*}{ 1995-1996 } & S1 & 572.47 & 135.85 & 104.16 & 270.29 & 63.78 & 110.56 & 1257.11 \\
\hline & S2 & 891.79 & 210.00 & 160.24 & 419.50 & 98.73 & 169.34 & 1949.60 \\
\hline & S3 & 1676.59 & 392.15 & 301.07 & 795.80 & 185.74 & 316.66 & 3668.01 \\
\hline \multirow{3}{*}{ 1996-1997 } & S1 & 554.58 & 133.38 & 96.07 & 245.90 & 59.48 & 103.04 & 1192.45 \\
\hline & S2 & 777.84 & 186.24 & 138.97 & 355.59 & 85.65 & 148.84 & 1693.14 \\
\hline & S3 & 1407.23 & 335.53 & 251.60 & 647.92 & 155.20 & 268.63 & 3066.11 \\
\hline \multirow{3}{*}{ 1998-1999 } & S1 & 2.33 & 0.62 & 0.26 & 4.64 & 3.03 & $1.53 \mathrm{E}-06$ & 10.89 \\
\hline & S2 & 3.21 & 0.86 & 0.36 & 6.41 & 4.18 & $1.08 \mathrm{E}-05$ & 15.01 \\
\hline & S3 & 5.17 & 1.38 & 0.57 & 10.34 & 6.72 & 4.59E-06 & 24.18 \\
\hline \multirow{3}{*}{ 2001-2002 } & S1 & 820.44 & 225.58 & 146.51 & 119.41 & 98.12 & 112.56 & 1522.62 \\
\hline & S2 & 1306.08 & 320.23 & 229.48 & 191.43 & 148.09 & 180.14 & 2375.45 \\
\hline & S3 & 2852.82 & 678.92 & 509.73 & 414.76 & 318.42 & 389.05 & 5163.70 \\
\hline
\end{tabular}


Table 7. Irrigated area (hectare) for durum wheat by six reservoirs for the three irrigation scenarios S1, S2 and S3 for the selected seasons.

\begin{tabular}{cccccccccc}
\hline \multirow{2}{*}{ Seasons } & Scenario & Res. 1 & Res. $\mathbf{c}$ & Res. 3 & Res. 4 & Res. 5 & Res. 6 & Total \\
& S1 & 460.80 & 109.20 & 83.14 & 215.85 & 51.12 & 88.20 & 1008.32 \\
$\mathbf{1 9 9 5 - 1 9 9 6}$ & S2 & 673.94 & 159.75 & 123.02 & 320.29 & 75.29 & 131.53 & 1483.83 \\
& S3 & 1262.67 & 295.91 & 226.78 & 597.73 & 139.86 & 238.85 & 2761.80 \\
& S1 & 443.24 & 108.11 & 77.23 & 197.56 & 47.81 & 82.87 & 956.83 \\
$\mathbf{1 9 9 6 - 1 9 9 7}$ & S2 & 633.30 & 151.63 & 109.88 & 281.68 & 68.04 & 117.76 & 1362.30 \\
& S3 & 1065.75 & 254.51 & 190.45 & 489.22 & 117.44 & 203.60 & 2320.97 \\
$\mathbf{1 9 9 8 - 1 9 9 9}$ & S1 & 2.33 & 0.62 & 0.26 & 3.33 & 2.34 & $1.33 \mathrm{E}-06$ & 8.88 \\
& S2 & 3.21 & 0.86 & 0.36 & 5.35 & 3.49 & $9.57 \mathrm{E}-06$ & 13.27 \\
& S3 & 5.17 & 1.38 & 0.57 & 8.53 & 5.54 & $3.73 \mathrm{E}-06$ & 21.19 \\
& S1 & 658.64 & 176.25 & 113.24 & 95.62 & 75.72 & 90.10 & 1209.55 \\
& S2 & 1009.84 & 260.79 & 176.88 & 147.34 & 118.60 & 138.65 & 1852.10 \\
& S3 & 1983.84 & 472.79 & 352.36 & 292.09 & 220.48 & 274.15 & 3595.72 \\
\hline
\end{tabular}

1522.62 ha respectively, while for scenario $\mathrm{S} 2$ it reached up to $1949.60,1693.14,15.01$, and 2375.45 ha respectively. For scenario S3 it reached up to $3668.01,3066.11$, 24.18 , and 5163.70 ha respectively.

The effect of combining both rainfall and SI will reduce the applied irrigation water to the wheat crop (bread and durum) that leads to make more water available for extra land along the seasonal growth of wheat crop in certain necessary amount and distribution of water. The SI processes minimize the water stress of the crop and compensates the lack of soil moisture that may accrued as a result of inadequate amount and distribution of rain water. Other benefit of SI processes is that during the late stages of crop growth, where the rainfall stop, SI processes is very necessary to reduce water stress which is very important to achieve stable yields [23].

Although the prime affecting factor is rain water, the results indicates that reduction of supplemental irrigation levels leads to increase the irrigated area by using harvested runoff water for SI processes.

Increasing the area of agricultural land is a primary goal that leads to satisfy the increase of wheat yield. In order to evaluate the wheat yield, it should be consider, the total water applied (rainfall + irrigation water) to the crop, using wheat crop yield-water use relationship of International Center for Agricultural Research in the Dry Areas (ICARDA) [23] as follows:

In this research, the wheat yield is investigated for both bread and durum wheat, using yield relation with total applied water conducted by ICARDA considering the irrigated area under three level of SI $(100 \%, 75 \%$, and $50 \%$ ) of full irrigation requirements.
The wheat yield per unit area for each wheat type was tested for two cases. The first is that the wheat crop depending on total water (rain + irrigation) that represents supplemental irrigation condition. The second is that the wheat crop depending on the rain water alone (rain-fed condition). These two cases give four yield scenarios for each type of wheat, three of them for supplemental irrigation condition and one scenario for rain-fed condition (Tables 8 and 9).

The results show that, the grain yield of wheat per unit area (scenario Y4) under rain-fed condition for the selected seasons reached up to $5.29,2.54,0.0$, and 1.46 (t/ha) for bread wheat respectively (Table 8), and for durum wheat, reached up to $4.93,2.19,0.0$, and 1.18 (t/ha) (Table 9), which is always less than the grain yield of wheat per unit area under supplemental irrigation condition.

Rapid assessment of the scenario Y4 for bread and durum shows that these results are within the range of grain yield of wheat crop, under rain-fed conditions, except dry season which is under $200 \mathrm{~mm}$ of rainfall depth.

According to ICARDA, under rain-fed conditions (irrigation water $=0$ ), grain yield of both bread and durum wheat increase from 1.2 to $4-5 \mathrm{t} / \mathrm{ha}$ when rainfall increased from 250 to $450 \mathrm{~mm}$.

The wheat yield of bread and durum for wet season seem convincing as a result of availability of rainwater that reaches up to $478.4 \mathrm{~mm}$ during the wet season (1995-1996). Although the conditions of the wet season gave good results for wheat yield but the rain water that reached the crop during this season cannot be guaranteed during other seasons. On the other hand, the wheat grain 
Table 8. Grain yield of bread wheat per unit area under supplemental irrigation and rainfall conditions.

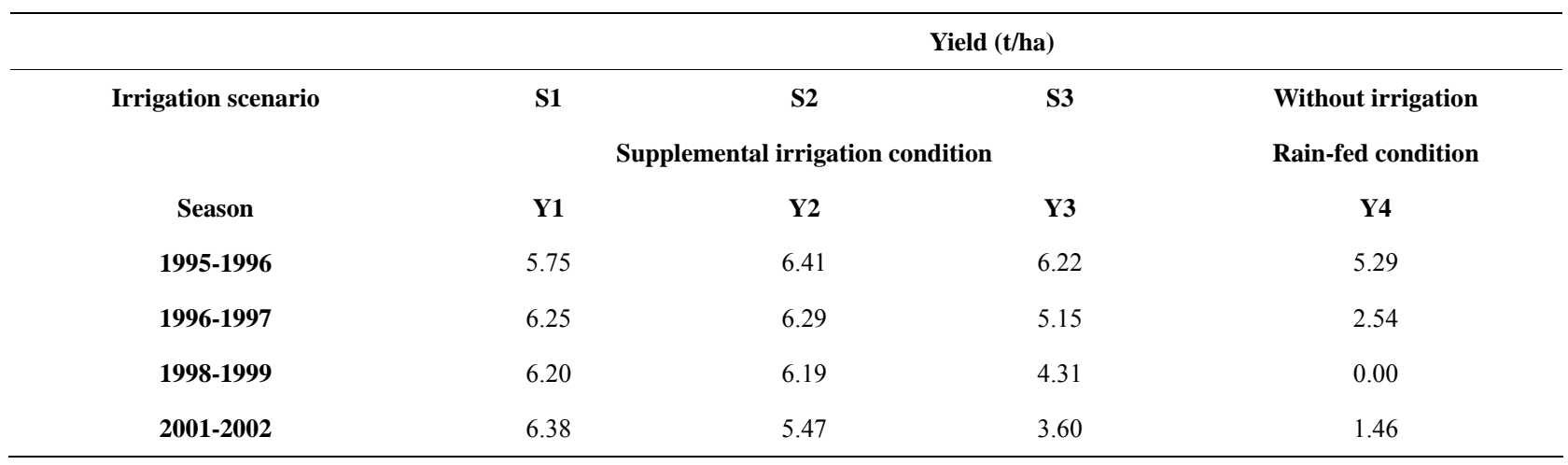

Table 9. Grain yield of durum wheat per unit area under supplemental irrigation and rainfall conditions.

\begin{tabular}{ccccc}
\hline & \multicolumn{2}{c}{ Yield (t/ha) } \\
\hline Irrigation scenario & \multicolumn{1}{c}{$\mathbf{S 1}$} & $\mathbf{S 2}$ & $\mathbf{S 3}$ & Without irrigation \\
& \multicolumn{2}{c}{ Supplemental irrigation condition } & & Rain-fed condition \\
Season & $\mathbf{Y 1}$ & $\mathbf{Y 2}$ & $\mathbf{Y 3}$ & $\mathbf{Y 4}$ \\
$\mathbf{1 9 9 5 - 1 9 9 6}$ & 5.89 & 6.64 & 6.30 & 4.93 \\
$\mathbf{1 9 9 6 - 1 9 9 7}$ & 6.41 & 6.54 & 5.38 & 2.19 \\
$\mathbf{1 9 9 8 - 1 9 9 9}$ & 6.25 & 6.52 & 4.79 & 0.00 \\
$\mathbf{2 0 0 1 - 2 0 0 2}$ & 6.64 & 5.89 & 3.96 & 1.18 \\
\hline
\end{tabular}

yield per unit area dropped to zero for the dry season, this is due to the fact that the total amount of rainfall didn't exceed the threshold for the first gain of grain yield, where the considerable threshold for the first gain of grain yield is about $200 \mathrm{~mm}$. This value is similar to the threshold for the first gain yield increment for winter wheat in the US Southern Plains $[23,27]$. As well as the rainfall depth during dry season $(110.1 \mathrm{~mm})$ also did not produce enough runoff, in addition, these amount of rainfall alone is not enough for growth wheat crop. In the same time, grain yield of bread and durum wheat per unit area for the average and additional seasons didn't reach the maximum limit of wheat grain yield per unit area (4 $5 \mathrm{t} / \mathrm{ha}$ ). This gives an indicator that, there is a chance to increase the grain yield if other water source is available. The average and additional seasons represent the prevailing situation in rain-fed areas of Sinjar district.

Accordingly, the dependence on rainfall only in the arid rain-fed farms as a water source for the crops will always give a low crop yield as a result of the fluctuating of the rainfall. In order to increase the crop yield in rainfed farms it should be supplemental the rainfall by irrigation water [28]. To achieve this, rainwater harvesting technique is to be used to ensure water availability.

Crop yield per unit area is a function of the total amount of water that reaches the crop. The yield can be improved by increase the total amount of water. Thus, using supplemental irrigation with different irrigation level can enhance the crop yield in the rain-fed farms and helps to find out the minimum amount of applied irrigation water that gives maximum crop yield.

For the selected seasons, the rainfall was 478.1, 110.1, $257.5,307.6(\mathrm{~mm})$ respectively , the use of supplemental irrigation scenario S2 instead of S1 increases grain yield per unit area for the seasons 1995-1996 and 1996-1997 by $11.48 \%, 0.64 \%$, and it decreased for the seasons $1998-1999$ and $2001-2002$ by $0.16 \%$ and $14.26 \%$ for bread wheat. For durum wheat, the grain yield per unit area increased for the seasons 1995-1996, 1996-1997 and $1998-1999$ by $12.73 \%, 2.03 \%, 4.32 \%$, and decreased for the season $2001-2002$ by $11.3 \%$.

While the use of supplemental irrigation scenario S3 instead of S1 leads to increase the yield per unit area for the season $1995-1996$ by $8.17 \%$, and decreased for other seasons by $17.60 \%, 30.48 \%$, and $43.57 \%$ respectively for bread wheat. For durum wheat, the yield per unit area had been increased for the seasons $1995-1996$ by $6.96 \%$, and decreased for other seasons by $16.07 \%, 23.36 \%$, and $40.36 \%$ respectively.

The reasons of the increased or decreased yield per unit area can be explained as follow:

In general, reduction of the total amount of applied water to the crop leads to decrease the yield per unit area. This is true for linear relation, but it was found that the 
grain yield linearly increase with increasing the summation of rain and the irrigation water up to $450 \mathrm{~mm}$ during the growing season [23]. When the summation of water was above $600 \mathrm{~mm}$, grain yield showed a plateau. Grain yield finally approached the maximum because either rain or irrigation water was left in the soil profile or percolated into deeper layers at high levels of water application. The increase in grain yield per unit of water summation gradually decreased when this summation was above $450 \mathrm{~mm}$.

The three selected supplemental irrigation (S1, S2, and S3) that used harvested runoff water contributed to enhanced wheat yield (Tables 8 and 9). The results of grain yield of bread and durum wheat per unit area for yield scenario Y1 was 5.75 to 6.38 and 5.89 to $6.64(\mathrm{t} / \mathrm{ha})$ with full irrigation requirement respectively. For yield scenario $\mathrm{Y} 2$ it was 5.47 to 6.41 and 5.89 to 6.64 (t/ha) with $75 \%$ of full irrigation requirements respectively. With $50 \%$ of full irrigation requirements, the yield scenario Y3 was 3.60 to 6.22 and 3.96 to $6.30(\mathrm{t} / \mathrm{ha})$ for bread and durum wheat during the four selected seasons respectively.

Thus, coupling the results of the Optimization Model (irrigated area, Tables 6 and 7) and the results of the wheat grain yield per unit area (Tables 8 and 9), for the three irrigation scenarios (S1, S2, and S3), helps to find the grain yield of wheat crop from irrigated area from each reservoir for the four selected seasons as shown in Figure 4 for bread wheat and in Figure 5 for durum wheat.

By taking the summation of grain yield, it could be

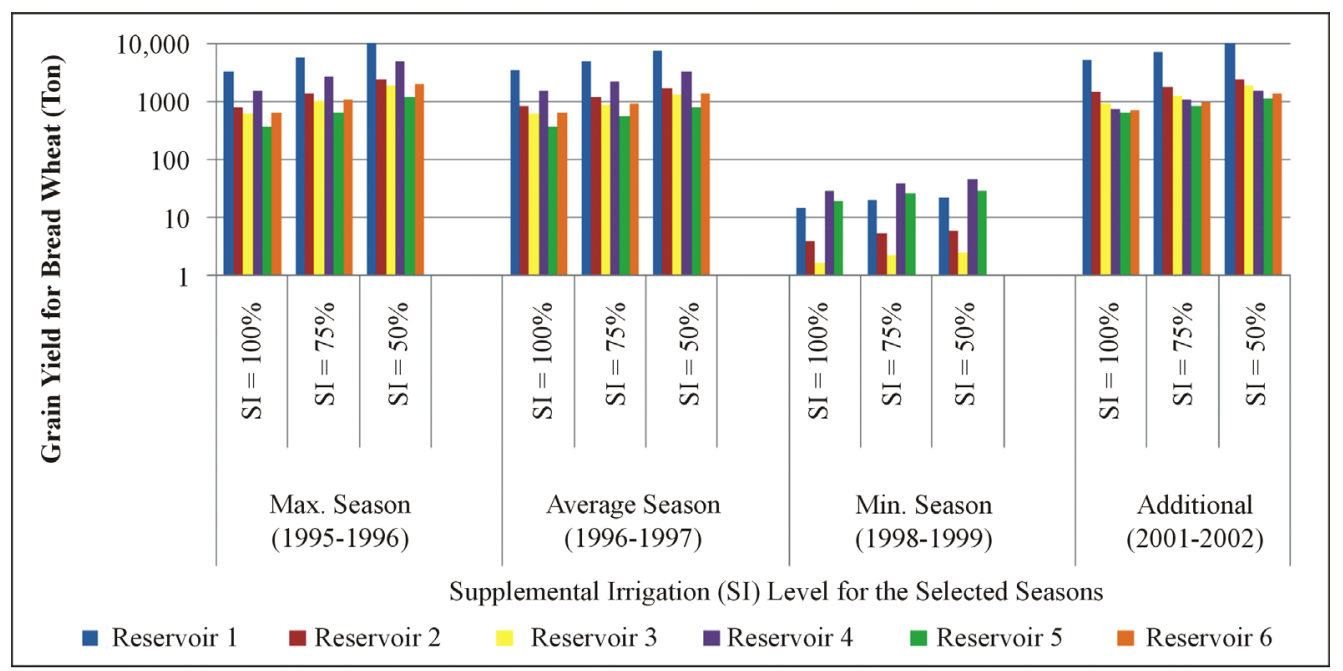

Figure 4. Grain yield for bread wheat for the irrigated area by the three irrigation level $(100 \%, 75 \%$, and $50 \%$ ) of crop irrigation requirement for the selected seasons.

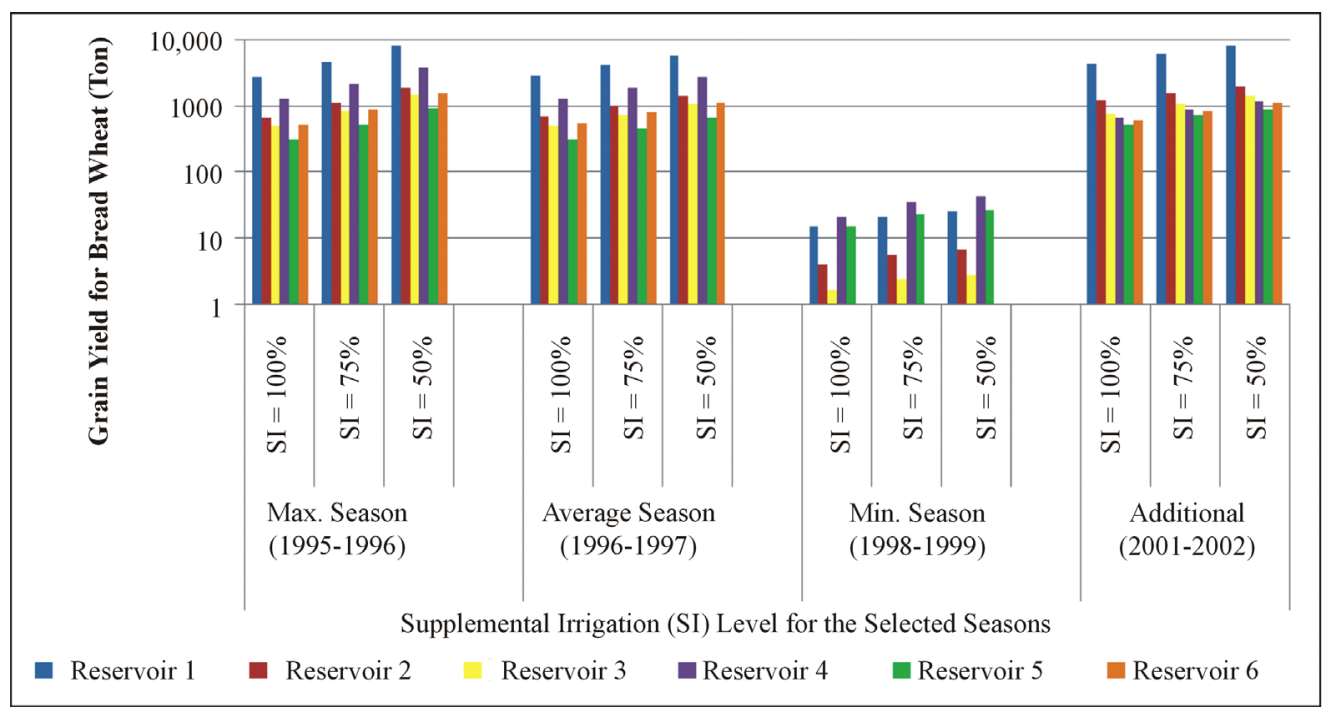

Figure 5. Grain yield for durum wheat for the irrigated area by the three irrigation level $(100 \%, 75 \%$, and $50 \%$ ) of crop irrigation requirement for the selected seasons. 
obtained the total grain yield of wheat crop (bread and durum) from irrigated area by all six reservoirs together thus:

The yield scenario Y1 gives 7223, 7457, 68 and 9712 Ton for bread wheat, and for durum wheat gives 5939, 6130,56 and 8035 Ton. The yield scenario Y2 gives 12,504, 10,658, 94 and 12,999 Ton for bread wheat, and for durum wheat gives 9859, 8913, 87, and 10,906 Ton. The yield scenario Y3 gives 22,806, 15,783, 105 and 18,603 Ton for bread wheat, and for durum wheat gives $17,396,12,478,103$, and 14,238 Ton for the four selected seasons (1995-1996, 1996-1997, 1998-1999 and 2001-2002) respectively.

The comparison for the total wheat grain yield among the three of supplemental irrigation scenarios (S1, S2, and S3) showed that scenario S3 gave always maximum total wheat grain yield for all the selected seasons and for both bread and durum wheat, and this is due to mainly two reasons as discussed below:

First, since the yield is a function of water that reach the crop, then using supplemental irrigation level of 50\% of full irrigation requirements leads to reduce the yield per unit area, but in the same time, this level of irrigation works to save maximum of irrigation water and distributed over a larger area which leads to maximize the total irrigated area.

Second, the overall increase in irrigated area has become the dominant factor, which covered the lack of yield per unit area, which led to maximize the overall yield of wheat grain for irrigated area.

\section{CONCLUSION}

Sinjar area north of Iraq is a typical rain-fed farm. The results indicated that, using rainwater harvesting technique gives total volume of harvested runoff that can be considered for irrigation practices, that reached up to $42.4,25.1,0.60,10.9\left(10^{6} \mathrm{~m}^{3}\right)$ during 1995-1996, 19961997, 1998-1999, and 2001-2002, respectively.

The results show that, the supplemental irrigation scenario S3 (50\% of full irrigation requirement) can save more water than scenarios S1 or S2 $(100 \%$ and $75 \%$ of full irrigation requirement).

The yield scenario Y3 (under $50 \%$ of full irrigation requirement) gives, 105 to 22,806 (Ton) for bread wheat, and for durum wheat gives, 103 to 17,396 (Ton). Scenario $\mathrm{Y} 3$ always gives the maximum total wheat grain yield for all the selected seasons compared to Y1, Y2, (the yields scenarios given by supplemental irrigation scenarios $\mathrm{S} 1, \mathrm{~S} 2$ respectively).

The results showed that bread wheat can satisfy larger irrigated area and grain yield than durum.

\section{ACKNOWLEDGEMENTS}

The authors would like to thank Iraqi Directorate General of Mete- orological and Seismology, Baghdad, Iraq, who provide daily meteorological data for the period 1990-2009. Deep thanks for Ninevah Directorate of Agriculture, Ninevah, Iraq, Ministry of Water Resources, North Al-Jazeera Irrigation project, who provides Agriculture data. Special thanks go to International Center for Agricultural Research in the Dry Areas (ICARDA), Aleppo, Syria for their published data about bread and durum wheat. As well as some ICARDA researchers (Dr. Shideed K. and Dr. Wilko Schweers), who provide some valuable guidance to deal with the wheat crop of bread and durum through personal correspondence with them.

Special thanks go to Dr. Boers Th. who supported the authors' research in the field of RWH.

The research presented has been financially supported by Luleå University of Technology, Sweden and by "Swedish Hydropower Centre-SVC" established by the Swedish Energy Agency, Elforsk and Svenska Kraftnät together with Luleå University of Technology, The Royal Institute of Technology, Chalmers University of Technology and Uppsala University. Their support is highly appreciated.

\section{REFERENCES}

[1] Oweis, T., Hachum, A. and Kijne, J. (1999) Water harvesting and supplemental irrigation for improved water use efficiency in dry areas. International Water Management Institute, SWIM 7, Colombo.

[2] Falkenmark, M., Fox, P., Persson, G. and Rockstrom, J. (2001) Water harvesting for upgrading of rain-fed agriculture: Problems analysis and research needs. Stockholm International Water Institute, Stockholm.

[3] Oweis, T. (1997) Supplemental irrigation: A highly efficient water-use practice. ICARDA Aleppo Syria 16.

[4] Oweis, T. and Hachum, A. (2009). Optimizing supplemental irrigation: Tradeoffs between profitability and sustainability. Agricultural Water Management, 96, 511-516. http://dx.doi.org/10.1016/j.agwat.2008.09.029

[5] Oweis, T. and Hachum, A. (2006) Water harvesting and supplemental irrigation for improved water productivity of dry farming systems in West Asia and North Africa. Agricultural Water Management, 80, 57-73.

[6] Reij, C., Mulder, P. and Begemann, L. (1988) Water harvesting for plant production. World Bank Technology Paper, Washington DC.

[7] Prinz, D. (1996) Water harvesting: Past and future. In: Pereira, L.S., Ed., Sustainability of irrigated agriculture. Proceedings, Nato Advanced Research Workshop, Vimeiro, Rotterdam, 135-144.

[8] Boers, T.M. and Ben-Asher, J. (1982) A review of rain-water harvesting. Agricultural Water Management, 5, 145 158. http://dx.doi.org/10.1016/0378-3774(82)90003-8

[9] Boers, T.M. (1994) Rainwater harvesting in arid and semi-arid zones. International Institute for Land Reclamation and Improvement (ILRI), 1-7.

[10] Finkel, H.J. and Finkel, M. (1986) Engineering measures: Water Harvesting. In: Finkel, H.J., Finkel, M. and Naveh, Z., Eds., Semi-Arid Soil and Water Conservation, CRC Press, Inc., Boca Raton, 93-101. 
[11] Siegert, K. (1994) Introduction to water harvesting: Some basic principles for planning, design and monitoring. Water Harvesting for Improved Agricultural Production, Proceedings of the FAO Expert Consultation, Cairo, Rome, FAO.

[12] Rogelio, N.C., Samuel, M.C., Wilfredo, B.S., Arnulfo, B.G., Gina, P.N., Karen, A.S., Katherine, M.M. and Sharon, V. de Vera (2006) Enhancing multi-functionality of agriculture through rainwater harvesting system. Paddy Water Environ, 4, 235-243. http://dx.doi.org/10.1007/s10333-006-0057-3

[13] Zakaria, S., Al-Ansari, N.A., Knutsson, S. and Ezz-Aldeen, M. (2012) Rain water harvesting and supplemental irrigation at Northern Sinjar Mountain, Iraq. Journal of Purity, Utility Reaction and Environment, 1, 121-141.

[14] Zakaria, S., Al-Ansari, N.A., Knutsson, S. and Ezz-Aldeen, M. (2012) Rain water harvesting at Eastern Sinjar Mountain, Iraq. Geoscience Research, 3, 100-108.

[15] Oweis, T. and Hachum, A. (2003) Improving water productivity in the dry areas of West Asia and North Africa. In: Kijne, W.J., Barker, R. and Molden, D., Eds., Water Productivity in Agriculture: Limits and Opportunities for Improvement, CABI Publishing, Wallingford, 179-197. http://dx.doi.org/10.1079/9780851996691.0179

[16] United Nations (2011) Convention to combat desertification, Committee for the Review of the Implementation of the Convention 10th Session (ICCD/CRIC(10)/21). Changwon, 11-20 October 2011.

[17] FAO (2011) Save and grow: A policymaker's guide to the sustainable intensification of smallholder crop production. FAO, Rome.

[18] Keating, B.A., Carberry, P., Bindraban, P.S., Senthold, A., Meinke, H. and Dixon, J. (2010) Eco-efficient agriculture: Concepts, challenges, and opportunities. Crop Science, 50, s1-s11.

[19] FAO (2002) Bread wheat improvement and production, Plant production and protection.
[20] Agriculture Statistical Atlas of Iraq (2011) Iraqi Ministry of Planning, Central Statistics Office.

[21] Adary, A., Hachum, A., Oweis, T. and Pala, M. (2002) Wheat productivity under supplemental irrigation in Northern Iraq. On-Farm water husbandry research report series, No. 2. International Center for Agricultural Research in the Dry Areas (ICARDA), Aleppo.

[22] Shideed, K.H. (2012) Informing policy development for sustainable and productive food production systems in dry areas. International Center for Agricultural Research in the Dry Areas (ICARDA), Aleppo.

[23] Zhang, H. and Oweis, T. (1999) Water-yield relations and optimal irrigation scheduling of wheat in the Mediterranean region. Agricultural Water Management, 38, 195211. http://dx.doi.org/10.1016/S0378-3774(98)00069-9

[24] Al Khalidy, K.A. (2004) Preparation of geographical information system for the South Jazira irrigation project with the aid of remote sensing data. Unpublished M.Sc. Thesis, Mosul University, Mosul.

[25] Rasheed, H., Mohammad, E. and Awchi, T. (1994) A field study on influence of initial moisture content on infiltration function. Al-Rafidain Engineering, 2, 1-10.

[26] Al-Ansari, N.A., Ezz-Aldeen, M., Knutsson, S. and Zakaria, S. (2013) Water harvesting and reservoir optimization of selected areas South Sinjar Mountain, Iraq. Engineering Hydrology, in press.

[27] Musick, J.T., Jones, O.R., Stewart, B.A. and Dusek, D.A. (1994) Water-yield relationships for irrigated and dryland wheat in the US Southern Plains. Agron, 86, 980-986. http://dx.doi.org/10.2134/agronj1994.0002196200860006 $\underline{0010 \mathrm{x}}$

[28] China State Construction Engineering Corporation (CSCEC) (1986) North Jazira irrigation project, design criteria. Nedeco. 